\title{
Piotr KUSPYS*
}

\section{Współpraca gospodarcza Polski i Ukrainy}

\section{Podstawy prawne polsko-ukraińskiej współpracy gospodarczej}

Chociaż do roku 1990 Polska i Ukraina należały do jednego bloku socjalistycznego, nie podejmowały bezpośredniej współpracy gospodarczej. Nie było ku temu ani warunków politycznych, ani podstaw formalnych. Wszelkie kontakty odbywały się przy udziale i za pośrednictwem centrali na Kremlu. Sytuacja zmieniła się dopiero po dezintegracji ZSRR. Reformy rynkowe w Polsce oraz odzyskanie niepodległości przez Ukrainę utworzyły zupełnie nową sytuację polityczną i ekonomiczną, umożliwiającą nawiązanie bezpośredniej współpracy gospodarczej między obydwoma krajami. Z uwagi na różnicę rozwiązań ustrojowych i inny poziom rozwoju gospodarczego w Polsce i na Ukrainie nie było to łatwe zadanie. Kooperację utrudniała także niekomplementarność obydwu gospodarek i brak bazy prawnej. Jedynym dokumentem regulującym polskoukraińskie kontakty gospodarcze na początku lat dziewięćdziesiątych była Deklaracja o zasadach i podstawowych kierunkach rozwoju stosunków polskoukrainskich podpisana 13 października 1990 roku w Kijowie. Skupiając się głównie na kwestiach politycznych, nie zawierała ona szczegółowych przepisów odnoszących się do zagadnień gospodarczych, co znacznie ograniczało podejmowanie i rozwijanie kontaktów handlowych.

Trwały kryzys gospodarczy w ZSRR, który jeszcze bardziej pogłębił się po rozpadzie w 1991 roku Związku Radzieckiego, spowodował załamanie się ukraińskiej gospodarki. Według oficjalnych danych ukraiński dochód narodowy, w porównaniu z rokiem poprzednim, spadł o $4 \%$, a produkcja rolna i przemysłowa o $12 \%$. Wówczas obroty handlowe między Polską i Ukrainą wynosiły niespełna 180 mln USD ${ }^{1}$. Niemniej jednak Polska znalazła się na drugim miejscu na liście partnerów handlowych Ukrainy spoza WNP. Dlatego też pierwszym porozumieniem między Warszawą i Kijowem podpisanym po odzyskaniu przez Ukrainę niepodległości stała się Umowa między Rządem Rzeczypospolitej Polskiej i Rzadem Ukrainy o handlu i wspótpracy gospodarczej zawarta 4 października 1991 roku w Warszawie. Była ona ramowym dokumentem międzynarodowym regulującym bilateralne stosunki ekonomiczne. Zawarte w niej postanowienia określały formę wzajemnych rozliczeń (w walutach wymienial-

* Autor jest doktorantem Instytutu Nauk Politycznych i Stosunków Międzynarodowych Uniwersytetu Jagiellońskiego. Artykuł wpłynął do redakcji w lutym 2008 r.

1 Do tej liczby należy doliczyć obroty realizowane za pośrednictwem Moskwy, których nie uwzględniają statystyki ukraińskie. Szacuje się, że jest to około $40 \%$ polsko-ukraińskiej wymiany handlowej. 
nych lub jako operacje barterowe), regulowały zasady współpracy gospodarczej na poziomie regionalnym oraz precyzowały formę bezpośrednich kontaktów między przedsiębiorstwami. Dokument ten umożliwiał zawieranie kontraktów indywidualnych. Obydwa państwa przyznały sobie klauzulę najwyższego uprzywilejowania w odniesieniu do ceł, podatków i formalności dotyczących importu i eksportu towarów i usług. Określono również sposoby realizowania tej współpracy między innymi poprzez wymianę przedstawicieli handlowych, powoływanie i tworzenie wspólnych przedsiębiorstw, wymianę specjalistów i usług consultingowych, wspólne prace naukowo-badawcze w tym zakresie oraz poprzez organizowanie wystaw i targów. Gdy w 2005 roku zawarto nową Umowe między Rzqdem Rzeczypospolitej Polskiej a Gabinetem Ministrów Ukrainy o wspótpracy gospodarczej (4 marca 2005 roku) listę wzajemnych zobowiązań poszerzono o intensyfikację stosunków gospodarczych w sferze inwestycji i innowacji, rozbudowę infrastruktury energetycznej i w dziedzinie transportu, usprawnienie zabezpieczeń finansowych dla podejmowanych przedsięwzięć gospodarczych, rozwój kooperacji w zakresie usług oraz wymianę informacji handlowych i prawnych.

W 1991 roku rozpoczęto prace nad Traktatem między Rzeczypospolita Polska a Ukrainq o dobrym sqsiedztwie, przyjaznych stosunkach $i$ wspótpracy, które zostały sfinalizowane przez jego podpisanie 18 maja 1992 roku. Jako dokument o najwyższej randze zawiera wiele przepisów regulujących wspólpracę w różnych dziedzinach, w tym także w zakresie kooperacji gospodarczej. W myśl znajdujących się w nim przepisów postanowiono, iż strony będą sprzyjać wzajemnie korzystnej współpracy gospodarczej, w tym handlowej, opartej na zasadach rynkowych, i zapewnią dogodne warunki takiej współpracy, z uwzględnieniem ochrony inwestycji, technologii, praw autorskich i patentowych, oraz będą dokonywać odpowiednich regulacji prawnomiędzynarodowych $w$ zakresie obiegu kapitałów, przepływu siły roboczej, towarów i usług. Wsparcie i ułatwienie tej współpracy ze strony państwa dotyczy w równym stopniu przedsiębiorstw państwowych, jak i prywatnych. Ten przepis był potwierdzeniem likwidacji monopolu państwa w kreowaniu międzynarodowej współpracy gospodarczej, co w państwach bloku socjalistycznego dotychczas funkcjonowało jako zasada.

\section{Przepływ osób i towarów}

Pierwszą regulacją w tym zakresie stała się Umowa między Rządem Rzeczypospolitej Polskiej i Rzqdem Ukrainy o międzynarodowych przewozach drogowych z 18 maja 1992 roku. Podpisana w celu rozwoju międzynarodowego transportu drogowego między obu państwami miała ona ułatwić przepływ osób i towarów zarówno pod względem formalnym, jak i faktycznym. Chodziło przede wszystkim o wypracowanie zasad organizacji regularnych i nieregularnych przewozów zorganizowanych grup podróżnych, a także przewozów towarów. Umowa określała procedurę formalną w zakresie uzyskiwania zezwoleń na wykonywanie przewozów osób i towarów. Taki sam cel przyświecał sygnatariuszom kolejnych dwóch dokumentów w tej dziedzinie, 
a mianowicie Umowy między Rządem Rzeczypospolitej Polskiej a Rzq̨dem Ukrainy o komunikacji kolejowej przez granice państwowa podpisanej 18 czerwca 1993 roku oraz Umowy między Rzq̨dem Rzeczypospolitej Polskiej a Rządem Ukrainy o komunikacji lotniczej z 20 stycznia 1994. O ile pierwszy dokument zawiera ogólne postanowienia dotyczące ruchu, infrastruktury kolejowej i współpracy pocztowej o charakterze porządkującym² ${ }^{2}$, drugi stanowi podstawę prawną dla uruchomienia bezpośrednich połączeń lotniczych.

Największe znaczenie dla ożywienia kontaktów bezpośrednich miała liberalizacja zasad ruchu osobowego. Na podstawie Umowy między Rzq̨dem Rzeczypospolitej Polskiej a Rzadem Ukrainy o ruchu bezwizowym, podpisanej 25 czerwca 1996 roku w Warszawie, zniesiono obowiązek wizowy. Przyczyniło się to do ekspansji zarówno turystycznej, jak i zarobkowej. W konsekwencji kilkaset tysięcy Ukraińców co roku przyjeżdżało do pracy w Polsce. Gdy w 2003 roku Polska wprowadziła wizy dla obywateli Ukrainy, ruch osoby przez granicę polsko-ukraińską znacznie zmniejszył się. Było to spowodowanie nie tyle skomplikowaną procedurą otrzymywania wiz, ile problemami technicznymi. Polskie placówki konsularne na Ukrainie nie nadążały z wydawaniem wiz dla wszystkich zainteresowanych, tym bardziej że wizy wystawiano bez pobierania opłaty konsularnej. Jest to istotny czynnik, który ma wpływ na migrację zarobkową do Polski. Szacuje się, że w roku 2005 w Polsce podejmowało pracę ponad 150 tys. Ukraińców. Ponadto liberalizacja przepisów wizowych przyczyniła się także do wzrostu nieewidencjonowanej wymiany handlowej, która odbywa się poprzez tak zwany handel walizkowy w strefie przygranicznej. Według niektórych ocen jego wartość może osiągać nawet $150 \mathrm{mln}$ USD rocznie $^{3}$. Przystąpienie Polski do strefy Schengen już spowodowało spadek dynamiki przygranicznej wymiany handlowej. Wprowadzenie odpłatnych wiz od 1 stycznia 2008 roku w wysokości 35 euro z katalogiem rozbudowanych wymagań formalnych stało się istotnym utrudnieniem dla Ukraińców chcących przyjechać do Polski. Niewątpliwie "turystyka handlowa” na pograniczu polsko-ukraińskim nie będzie już tak intensywna jak w poprzednich latach. Można jednak przypuszczać, że nowa polityka wizowa nie odbije się negatywnie na współpracy między Polską i Ukrainą. Większe zagrożenie dla stabilnego rozwoju stosunków gospodarczych mają tak zwane problemy systemowo-etyczne, które istnieją od lat na granicy polsko-ukraińskiej. Po stronie polskiej głównym niedociągnięciem służb granicznych jest ich liczebny niedostatek w stosunku do rzeczywistych potrzeb, co znaczne wydłuża odprawę celną. Problem ten

2 Współpraca w zakresie komunikacji pocztowej realizowanej za pośrednictwem kolei była przedmiotem Porozumienia między Ministerstwem Eqczności RP a Ministerstwem Eqczności Ukrainy o wspótpracy w dziedzinie poczty i telekomunikacji, Warszawa 17.06.1993, Departament Prawny Ministerstwa Spraw Zagranicznych RP. W 2005 roku została zawarta umowa międzyrządowa. Zob. Umowa między Rządem RP a Gabinetem Ministrów Ukrainy o wspótpracy w dziedzinie poczty i telekomunikacji, Kijów, 4.03.2005, Departament Prawny Ministerstwa Spraw Zagranicznych RP.

3 Według innych danych w 1996 roku Ukraińcy wydali w Polsce 1248,9 mln zł, co stawia ich na drugim miejscu tuż po Niemcach jeśli chodzi o dokonywanie zakupów Polsce. 
narastał od lat i w tym roku osiągnął poziom krytyczny, znajdując potwierdzenie w licznych protestach przewoźników, jak i samych celników w całym kraju. Jeśli chodzi o ukraińską granicę, pozostaje ona w dużym stopniu granicą nieprzewidywalną. Nie wiadomo bowiem, jak długo potrwa odprawa i co należy zrobić, aby nie stać godzinami na przejściu. Oczywiście można tutaj przytaczać różne powody, jednak podstawową kwestią pozostaje problem korupcji i niejasnych układów.

\section{Regulacje międzyresortowe}

W celu tworzenia rzeczywistości prawnej sprzyjającej pogłębianiu kontaktów gospodarczych między dwoma krajami na różnych płaszczyznach 19 maja 1994 roku w Kijowie podpisano Porozumienie o wspótpracy między Ministerstwem Gospodarki Przestrzennej i Budownictwa Rzeczypospolitej Polskiej a Ministerstwem Budownictwa i Architektury Ukrainy. W myśl zawartych w nim postanowień obydwa państwa zobowiązały się do zacieśnienia kooperacji w dziedzinie planowania przestrzennego, urbanistyki, mieszkalnictwa i gospodarki komunalnej. Przewidziano także wymianę doświadczeń w tym zakresie oraz popieranie doskonalenia zawodowego osób bezpośrednio zajmujących się wspomnianą problematyką. Organem odpowiedzialnym za tę kooperację jest Polsko-Ukraińska Komisja Gospodarki Przestrzennej powołana na mocy Porozumienia między Ministerstwem Gospodarki Przestrzennej i Budownictwa Rzeczypospolitej Polskiej a Państwowym Komitetem Ukrainy do Spraw Urbanistyki i Architektury o utworzeniu Polsko-Ukraińskiej Komisji Gospodarki Przestrzennej z 25 czerwca 1996 roku. Do najważniejszych zadań Komisji dotyczących kooperacji gospodarczej należą: wymiana informacji i wzajemne konsultacje w dziedzinie gospodarki przestrzennej oraz przygotowywanie propozycji badań i opracowań dla potrzeb rejonów przygranicznych.

Współpraca międzyresortowa w zakresie wymiany informacji dotyczących organizacji i funkcjonowania rynku pracy w obydwu krajach, migracji zarobkowej i ochrony socjalnej stała się przedmiotem Umowy między Ministerstwem Pracy i Polityki Społecznej a Ministrem Pracy Ukrainy o wspótpracy w dziedzinie pracy i polityki społecznej z 16 lutego 1994 roku. Dokument ten nie wnosi żadnych regulacji mających bezpośredni wpływ na ułatwienie wzajemnego zatrudniania pracowników, podobnie jak Umowa między Rządem Rzeczypospolitej Polskiej a Rządem Ukrainy o wzajemnym zatrudnianiu pracowników podpisana $\mathrm{w}$ tym samym dniu. Zawarte $\mathrm{w}$ niej regulacje nie przyczyniły się do promocji wzajemnego zatrudnienia, gdyż nie zniosły utrudnień administracyjnych przewidzianych przez prawodawstwo wewnętrzne w obydwu krajach w odniesieniu do obywateli drugiej strony. Obecnie zarówno na Ukrainie, jak i w Polsce obowiązują rozbudowane przepisy, które skutecznie zapobiegają legalnemu podejmowaniu pracy przez obcokrajowców, stanowiąc swojego rodzaju zaporę dla rozwoju bezpośrednich stosunków gospodarczych. Na tym traci zarówno Polska, jak i Ukraina. Próbą zmiany takiego stanu było Rozporzadzenie Ministra Pracy i Polityki Społecznej w sprawie wykonywania pracy przez cudzoziemców bez 
konieczności uzyskania zezwolenia na pracę z 30 sierpnia 2006 roku. Umożliwiało ono legalne zatrudnianie obywateli państw ościennych podczas prac sezonowych w rolnictwie. 27 czerwca 2007 roku, w związku z organizacją przez Polskę i Ukrainę mistrzostw Europy w piłce nożnej w 2012 roku, ministerstwo to jeszcze bardziej zliberalizowało zasady zatrudniania Ukraińców w Polsce, umożliwiając podejmowanie pracy bez zezwolenia we wszystkich sektorach gospodarki.

Mówiąc o podstawach polsko-ukraińskiej współpracy gospodarczej warto zwrócić uwagę na instytucje i fora umożliwiające te kontakty. Jednym z takich miejsc jest Forum Ekonomiczne w Krynicy. Organizowane od kilkunastu lat przez Instytut Wschodni przedsięwzięcie pozwala na poruszenie ważnych tematów z zakresu wspólpracy polityczno-gospodarczej przy szerokim udziale przedstawicieli rządów, środowisk gospodarczych i ludzi nauki. Kolejnym takim forum o charakterze bilateralnym jest Polsko-Ukraiński Szczyt Gospodarczy, który odbywa się na przemian na Ukrainie i w Polsce. W spotkaniach przedstawicieli biznesu uczestniczą prezydenci obu krajów. Ponadto w Polsce działa Polsko-Ukraińska Izba Gospodarcza. Powołana w 1992 roku jako organizacja samorządu gospodarczego zrzesza polskie i ukraińskie podmioty zainteresowane współpracą gospodarczą. Zajmuje się promocją gospodarki polskiej na rynku ukraińskim, umożliwia nawiązywanie współpracy polskich i ukraińskich przedsiębiorstw oraz pomaga w zakładaniu działalności gospodarczej na terytoriach obu państw. Po stronie ukraińskiej działa Ukraińsko-Polskie Centrum Współpracy w zakresie Rozwoju Przedsiębiorczości, Zarządzania i Inwestycji w Dniepropietrowsku. Centrum zostało założone w 2001 roku przez Wyższą Szkołę Biznesu w Nowym Sączu, Uniwersytet Prawa i Ekonomiki w Dniepropietrowsku, spółkę OPTIMUS S.A. oraz ukraińską telekomunikację UKRTELECOM. Podejmuje ono takie same działania jak Polsko-Ukraińska Izba Gospodarcza w Polsce. Na Ukrainie działa również Międzynarodowe Stowarzyszenie Przedsiębiorców Polskich. Organizacja została założona w 1998 roku. Obecnie zrzesza ponad 200 przedstawicieli polskich spólek i przedsiębiorstw działających na rynku ukraińskim. Podejmuje działania na rzecz ochrony interesów swoich członków wobec polskich i ukraińskich władz.

\section{Wymiana handlowa}

Gdy w drugiej połowie 1991 roku Ukraina ogłosiła swoją niepodległość, oznaczało to zerwanie nie tylko politycznych więzi z Kremlem, ale również instytucjonalno-formalnych powiązań w innych dziedzinach współpracy. W sposób szczególny dotyczyło to międzynarodowej współpracy gospodarczej, która również była realizowana za pośrednictwem Moskwy. Uzyskanie przez Ukrainę niepodległości wiązało się z utratą dotychczasowych rynków i poszukiwaniem nowych. W znacznie lepszej sytuacji była Polska. Pomimo ścisłych powiązań z ZSRR, na początku lat dziewięćdziesiątych miała ona już wysoko rozwiniętą kooperację z państwami zachodnimi. Pojawienie się nowych państw pozwalało na podjęcie bezpośredniej współpracy handlowej, co było dla Polski ze 
wszech miar korzystne. Podczas gdy w 1991 roku kontakty te realizowano przez Moskwę, od następnego roku stały się one domeną poszczególnych rządów. Tak też stało się w przypadku współpracy polsko-ukraińskiej. W 1992 roku udział Ukrainy w polskim handlu zagranicznym wynosił około 1\%. Wartość wzajemnej wymiany handlowej zamknęła się kwotą $480 \mathrm{mln}$ zł z dodatnim dla Polski saldem w wysokości $30 \mathrm{mln}$ zł. Polska eksportowała na Ukrainę przede wszystkim paliwa i energię oraz wyroby przemysłu elektromaszynowego i lekkiego. Z kolei ukraiński eksport do Polski był zdominowany przez surowce dla przemysłu metalurgicznego i chemicznego oraz wyroby przemysłu spożywczego.

Koniec 1992 roku przyniósł nasilenie zjawisk kryzysowych w ukraińskiej gospodarce, co mogło negatywnie wpłynąć na wymianę handlową z Polską. Tak jednak się nie stało. W następnym roku wskaźniki wymiany gospodarczej wzrosły prawie o jedną trzecią, osiągając 699,6 mln zł. Polska nadal importowała z Ukrainy nisko przetworzone wyroby przemysłu metalurgicznego i chemicznego. Znaczący udział zarówno w imporcie, jak i w eksporcie zajmowały maszyny i sprzęt elektryczny. W eksporcie na Ukrainę na pierwszym miejscu znajdowały się surowce energetyczne. Nastąpił spadek handlu wyrobami przemysłu lekkiego, a prawie sześciokrotnie wzrósł polski eksport wyrobów przemysłu chemicznego.

Znaczne zwiększenie importu wyrobów przemysłu metalurgicznego z Ukrainy doprowadziło do powstania ujemnego dla Polski salda rzędu 23,3 mln zł. To jedyny rok, w którym bilans współpracy handlowej między Polską i Ukrainą był dla Warszawy ujemny. Nie miało to jednak większego znaczenia dla polskiej gospodarki, a poprawa sytuacji ekonomicznej na Ukrainie w 1994 roku zaowocowała wzrostem wartości wymiany handlowej do 1 mld zł. Wówczas polski eksport na Ukrainę wzrósł prawie dwukrotnie, przekraczając $643 \mathrm{mln}$ zł. Stało się to dzięki intensyfikacji wymiany towarowej w zakresie wiodącej produkcji w strukturze towarowej współpracy bilateralnej. Polska podwoiła eksport surowców energetycznych (paliw i produkcji pochodnej) i wyrobów elektromaszynowych. Wartość eksportu wyrobów przemysłu spożywczego wzrosła trzykrotnie. W imporcie nadal dominowała produkcja metalurgiczna i chemiczna oraz ponownie wzrósł handel artykułami spożywczymi. Ta struktura w handlu bilateralnym utrzymała się również w następnym roku, który był rokiem polskiej ekspansji gospodarczej na rynek ukraiński. Polski eksport wyniósł 1,8 mld zł, podczas gdy import z Ukrainy wzrósł nieznacznie, osiągając $704 \mathrm{mln}$ zł. Ukraina stała się drugim po Rosji partnerem handlowym wśród państw WNP oraz siódmym importerem polskich wyrobów na świecie 4 . Polska z kolei awansowała na czwarte miejsce wśród partnerów gospodarczych Ukrainy tuż po Rosji, Niemczech i Włoszech. Jednakże wzrost ilościowy we współpracy handlowej nie szedł w parze ze wzrostem jakościowym. Polska

4 W 1992 roku Ukrainy nie było na liście wśród pierwszej dziesiątki ważnych partnerów handlowych Polski. 
eksportowała przede wszystkim artykuły rolno-spożywcze, Ukraina zaś - węgiel i rudy żelaza 5 .

Rok 1996 przyniósł dalszy wzrost obrotów handlowych, których wartość przekroczyła 3,7 mld zł, z dodatnim dla Polski saldem rzędu 1,5 mld zł. Struktura towarowa nadal była zdominowana przez import surowców z Ukrainy. Znacznie wzrosła wartość sprowadzanej z Ukrainy żywności - $218 \mathrm{mln}$ zł. Było to jednak dwukrotnie mniej niż polski eksport produktów z tej kategorii na Ukrainę. Jednak na pierwszym miejscu na liście polskiego eksportu znalazły się różne wyroby przemysłowe, a następnie produkcja przemysłu chemicznego. Na trzeciej pozycji znalazły się paliwa mineralne i materiały pochodne. W następnym roku polski import $\mathrm{w}$ tym zakresie wzrósł dwukrotnie. W konsekwencji obroty handlowe w 1997 roku zamknęły się kwotą 5,3 mld zł (w tym import 1,3 mld zł, eksport prawie 4,0 mld zł).

Pogorszenie się koniunktury gospodarczej na Ukrainie i w Rosji w drugiej połowie 1998 roku negatywnie wpłynęło na polsko-ukraińską współpracę ekonomiczną. Po raz pierwszy od 1992 roku odnotowano spadek obrotów handlowych, które wyniosły 5,1 mld zł. O ile pierwsza połowa roku zapowiadała się bardzo obiecująco, we wrześniu sytuacja zmieniła się. Deprecjacja ukraińskiej waluty (hrywny), która trwała do października 1999 roku, doprowadziła do spadku zdolności nabywczej Ukrainy w odniesieniu do polskich towarów. Ponadto w celu ochrony własnej produkcji strona ukraińska wprowadziła ostre ograniczenia administracyjne, celne oraz inne środki ochronne. W konsekwencji odnotowano spadek polskiego eksportu o ponad $40 \% \mathrm{w}$ odniesieniu do wskaźników osiągniętych w pierwszym półroczu. Wówczas wartość wzajemnej wymiany handlowej wyniosła 4,1 mld zł. Podczas gdy import z Ukrainy pozostawał na tym samym poziomie, wartość polskiego eksportu spadła poniżej 3 mld zł. Zasadniczy wpływ na taki stan rzeczy miało załamanie się eksportu węgla i materiałów pochodnych. W 1998 roku wartość obrotów w tym zakresie wynosiła 436 mln zł, a w 1999 roku - 81 mln zł.

Dla poprawienia wyników współpracy gospodarczej potrzeba było dwóch lat. W 2000 roku odnotowano wyraźne ożywienie, które zaowocowało zwiększeniem wartości wymiany handlowej do 5,4 mld zł, z dodatnim saldem dla Polski o wartości 1,4 mld zł. Nastąpiła poprawa we wszystkich dziedzinach handlu z wyjątkiem napojów i tytoniu. Znacznie wzrósł eksport paliw mineralnych, który w 1999 roku się załamał. Największe jednak przychody nadchodziły z tytułu eksportu towarów przemysłowych i produkcji chemicznej. Od tego momentu towary i wyroby przemysłowe stały się wiodącą pozycją w strukturze polskiego eksportu. W imporcie z Ukrainy przeważały surowce

5 Na Ukrainie wciąż utrzymywano ten sam poziom zatrudnienia i nie czyniono żadnych kroków w kierunku poprawy sytuacji ukraińskiego górnictwa. Z uwagi na jego niedoinwestowanie wydobycie węgla spadało z roku na rok. Podczas gdy w 1989 roku na Ukrainie wydobywano ponad 179 mln ton węgla, w roku 1995 wydobycie spadło do 84 mln ton. Stąd też od 1993 roku zwiększał się import tego surowca z Polski, zwłaszcza do zachodnich regionów kraju, gdyż na Ukrainie roczne zapotrzebowanie szacuje się na $100 \mathrm{mln}$ ton. 
energetyczne i metalurgiczne, których wartość stanowiła więcej niż połowę wartości całego importu.

Stabilizacja wymiany handlowej między Polską i Ukrainą, która nastąpiła w 2001 roku, miała charakter chwilowy. Wartość obrotów handlowych wzrosła do 5,9 mld zł. Wzrost ten był możliwy dzięki zwiększeniu polskiego eksportu towarów przemysłowych, których wartość po raz pierwszy przekroczyła 1 mld zł. W 2002 roku obroty handlowe utrzymywały się na tym samym poziomie. Nastąpił nieznaczny wzrost importu, wartość którego chociaż zwiększyła się do 2 mld zł, nie przekroczyła jednak wartości importu z 2000 roku. Wzrosły obroty w zakresie eksportu produkcji przemysłowej i sprzętu transportowego. Łączna wartość obrotów handlowych zamknęła się w 6,8 mld zł.

Podczas gdy do 2002 roku import z Ukrainy wykazywał tendencję spadkową, w 2003 roku nastąpił jego ponad 50-proc. wzrost. Wartość obrotów towarowych zwiększyła się $\mathrm{w}$ ciągu roku o blisko 38\% w stosunku do roku poprzedniego i przekroczyła 8,9 mld zł. Eksport z Polski na Ukrainę przewyższył polskie dostawy do Rosji o ponad 150 mln zł. W efekcie Ukraina stała się największym odbiorcą polskich towarów wśród krajów Wspólnoty Niepodległych Państw i dziewiątym partnerem Polski w eksporcie ogółem (z udziałem na poziomie 2,9\%). Polska z kolei była dla Ukrainy siódmym partnerem w eksporcie i czwartym w imporcie. W polskim eksporcie główne miejsce zajmowały towary i wyroby przemysłowe, sprzęt transportowy i elektryczny, metale nieszlachetne oraz produkty przemysłu chemicznego. Najważniejszą pozycją towarową były samochody osobowe, których udział w eksporcie przekroczył 10\%. Taki wzrost nastąpił dzięki zawarciu kontraktu na sprzedaż samochodów Lanos. W imporcie z Ukrainy dominowały rudy żelaza i koncentraty, wyroby walcowane ze stali niestopowej, produkty mineralne (ropa, gaz) oraz towary przemysłowe.

W 2004 roku struktura towarowa pozostała bez zmian. Przystąpienie Polski do Unii Europejskiej i objęcie jej porozumieniami podpisanymi między UE i Ukrainą nie miało większego wpływu na kształt współpracy polsko-ukraińskiej. Niemniej jednak nowa sytuacja polityczna spowodowała zmniejszenie ukraińskiego eksportu o 14\%. Stało się tak z uwagi na zmniejszenie importowanych z Ukrainy surowców mineralnych i czarnych metali, będących podstawą ukraińskiego eksportu do Polski. Było to konsekwencją objęcia Polski unijnym systemem kontyngentów ilościowych, ustanawiającym limity na import produkcji przemysłu metalurgicznego z Ukrainy ${ }^{6}$. Dotychczas w ciągu roku Polska importowała z Ukrainy więcej wyrobów metalurgicznych niż wszystkie państwa Unii Europejskiej łącznie. Po 2004 roku roczny kontyngent na import stali z Ukrainy do UE był mniejszy od dotychczasowego rocznego importu stali z Ukrainy do Polski.

6 Przystąpienie Polski do Unii Europejskiej spowodowało istotne zmiany w polityce handlowej, jak i w strukturze instytucjonalnej. Dziedzina ta stała się domeną Komisji Europejskiej i Rady Unii Europejskiej. Polska także przyjęła dorobek prawny w tym zakresie Unii Europejskiej i tym samym przestały obowiązywać dotychczasowe regulacje wewnętrzne, jak i porozumienia międzynarodowe. Polska przyjęła wszystkie zasady i instrumenty wspólnej polityki handlowej w odniesieniu do krajów trzecich. 
Znaczna rozpiętość między wartością eksportu i importu, która nastąpiła w 1996 roku, w kolejnych latach sukcesywnie powiększała się. Wynikało to z tempa rozwoju obydwu gospodarek oraz ze struktury towarowej ukraińsko-polskiej wymiany handlowej. Do połowy lat dziewięćdziesiątych w polskim eksporcie dominowały paliwa mineralne i materiały pochodne. W 1996 roku na pierwsze miejsce pod względem wartości wysunęła się produkcja i towary przemysłowe. Od 2001 roku obserwuje się sukcesywny wzrost eksportu produkcji o wyższym stopniu przetworzenia. Chodzi o różnego typu maszyny i urządzenia. Dwa lata później do największej grupy eksportowanej produkcji dołączyły wyroby przemysłu chemicznego. W rezultacie w polskim eksporcie na Ukrainę dominuje obecnie 8 grup towarowych, które stanowią łącznie $80 \%$ wartości polskiego eksportu do tego kraju: wyroby przemysłu elektromaszynowego, chemicznego, metale nieszlachetne, wyroby przemysłu lekkiego, artykuły rolno-spożywcze, drewno, papier i tektura. Taka rozbudowana struktura towarowa eksportu na Ukrainę jest ze wszech miar korzystna dla polskiej gospodarki. Negatywne tendencje w wymianie handlowej w odniesieniu do którejkolwiek grupy towarów nie spowodują jej gwałtowanego załamania się.

Podczas gdy struktura polskiego eksportu na Ukrainę jest znacznie zdywersyfikowana, ukraiński eksport do Polski koncentruje się na trzech grupach towarów. Są to przede wszystkim wyroby przemysłu metalurgicznego i chemicznego oraz produkty mineralne. Ich udział stanowi ponad $80 \%$ eksportu z Ukrainy do Polski. W drugiej połowie lat dziewięćdziesiątych importowane z Ukrainy surowce mineralne i metale, które niegdyś plasowały się na pierwszym miejscu, przesunęły się na drugą pozycję, ustępując miejsca towarom przemysłowym. Ich udział w ogólnych obrotach handlowych między Polską i Ukrainą do 2005 roku wzrósł prawie do 50\%. Udział towarów o wysokim stopniu przetworzenia wciąż pozostaje niski - najważniejsze z nich to części do szybowców i samolotów, maszyny i urządzenia do obróbki metali, silniki turboodrzutowe i turbinowe oraz turbiny gazowe.

\section{Współpraca inwestycyjna}

\section{Sektor przemysłowy}

Wzrost obrotów handlowych między Polską i Ukrainą, szybko rozwijająca się polska gospodarka oraz chłonność ukraińskiego rynku umożliwiły zaangażowanie inwestycyjne oraz podjęcie bezpośredniej kooperacji produkcyjnej między polskimi i ukraińskimi przedsiębiorstwami. Niższe niż w Polsce koszty pracy oraz poprawiający się klimat inwestycyjny (wprowadzenie w drugiej połowie lat dziewięćdziesiątych Specjalnych Stref Ekonomicznych na Ukrainie) przekonały wielu inwestorów do zacieśnienia kontaktów biznesowych i ulokowania kapitału na Ukrainie. Wiązało się to z pewnym ryzykiem związanym z niestabilnością ukraińskiej gospodarki. Jednak nie przeszkodziło to w podjęciu takiej współpracy, chociaż początkowo w bardzo ograniczonym stopniu. Gorzej było z ukraińskimi inwestycjami w Polsce. Trwająca na Ukrainie prywatyzacja 
spowodowała, iż ukraińscy przedsiębiorcy byli skoncentrowani przede wszystkim na rodzimym rynku.

Na początku lat dziewięćdziesiątych wzajemne zaangażowanie inwestycyjne polskiego i ukraińskiego kapitału było nieznaczne. Wartość polskich inwestycji na Ukrainie była zdecydowanie wyższa niż ukraińskich w Polsce i do 1995 roku przekroczyła $12 \mathrm{mln}$ USD. W drugiej połowie lat dziewięćdziesiątych można zauważyć ożywienie w tym sektorze. Już w 1996 roku wartość polskich inwestycji wzrosła prawie dwukrotnie, gdyż wyniosła 20 mln USD, a w 1997 roku polski kapitał ulokowany na Ukrainie przekroczył 25 mln USD. Wówczas największym zainteresowaniem wśród polskich przedsiębiorców cieszył się sektor przemysłowy. Wykorzystując chłonność ukraińskiego rynku i zapotrzebowanie na różnego typu produkcję, otwierano własne linie produkcyjne oraz podejmowano kooperację w oparciu o polskie technologie. Do takich inwestycji zalicza się produkcję maszyn rolniczych, a zwłaszcza kombajnów zbożowych. Ukraina mogła samodzielnie zaspokoić zapotrzebowanie krajowe na tego typu sprzęt tylko w 50\%. Szybko to zauważyli producenci zagraniczni, którzy zaczęli sprowadzać na Ukrainę własny sprzęt. Wśród dostawców kombajnów znalazły się niemieckie, włoskie i francuskie przedsiębiorstwa, a w drugiej połowie lat dziewięćdziesiątych również polski „Bizon”. W 1997 roku, w celu uruchomienia na Ukrainie produkcji kombajnów zbożowych „Bizon”, utworzono polsko-ukraińską spółkę „Bizon-Ukraina”. Po dwuletnim „ręcznym” składaniu tych maszyn w oparciu o polskie rozwiązania konstrukcyjne w 1999 roku rozpoczęto seryjną produkcję kombajnów o nazwie "Obrij”.

$\mathrm{Z}$ podobnymi problemami borykała się także produkcja traktorów. Ukraina była $\mathrm{w}$ stanie zaspokoić tylko $62 \%$ potrzeb wewnętrznych. Braki uzupełniano eksportem z Czech, Włoch, Niemiec i Polski. W 1997 roku polska spółka „Ursus Trading", w oparciu o zawarte porozumienia, rozpoczęła montaż ciężkich ciągników rolniczych Ursus 1634 dla ukraińskich odbiorców.

Przez następne lata wartość polskiego kapitału na Ukrainie powiększała się średnio o 9 mln USD w ciągu roku. W konsekwencji do 2000 roku Polacy zainwestowali ponad $62 \mathrm{mln}$ USD. Wówczas z wielką inwestycją na ukraiński rynek wkroczyła Grupa Kapitałowa „Śnieżka” - producent wyrobów emulsyjnych i materiałów budowlanych. Pierwsza fabryka została uruchomiona w tymże roku w Jaworowie w obwodzie lwowskim. Inwestycja ta zamknęła się kwotą 5 mln USD. Dobre wyniki finansowe oraz ponad 40-procentowy udział w rynku w tej dziedzinie przesądziły o tym, że w 2005 roku założono drugą spółkę „Śnieżka-Ukraina II”. Budowa drugiej fabryki w Wistowej kosztowała $1 \mathrm{mln}$ USD.

W 2000 roku na ukraiński rynek weszła również „Peri Polska”. Przedsiębiorstwo to świadczy usługi inżynieryjne, zajmuje się doradztwem technicznym w zakresie deskowań i rusztowań. Jest także liczącym się producentem światowym w tej dziedzinie. Firma ma swoje oddziały w Kijowie, Odessie, Dniepropietrowsku i na Krymie. Wartość inwestycji szacuje się na 7 mln USD.

Do 2001 roku wartość polskich inwestycji przekroczyła 100 mln USD. Największe inwestycje zostały poczynione w przemyśle. Wśród liczących się 
polskich inwestorów znaleźli się producenci mebli: „Forte”, który zainwestował ponad $10 \mathrm{mln}$ USD oraz „Black Red White”, wartość inwestycji szacuje się na $8 \mathrm{mln}$ USD. W obwodzie lwowskim ruszyła także inwestycja związana z produkcją nowoczesnych aparatów telefonicznych „Cyfral”. W Nowowołyńsku bydgoski „Arkus \& Romet” wspólnie z Ukraińcami zainwestował 623 tys. USD w produkcję rowerów górskich.

W 2003 roku inwestycje nadal były wysokie. Polskie firmy zainwestowały wówczas 53 mln USD. Pod koniec 2003 roku na Ukrainie działało już 861 polskich przedsiębiorstw. Rok później ich liczba przekroczyła 940. Należy jeszcze doliczyć 580 spółek mieszanych z polsko-ukraińskim kapitałem. Wówczas ogólna wartość polskich inwestycji przekroczyła $170 \mathrm{mln}$ USD. W październiku 2003 roku polska firma „Can Pack” z Krakowa otworzyła w Wyszgorodzie, w obwodzie kijowskim, przedsiębiorstwo produkcyjne aluminiowych opakowań (puszek) - OOO Ken-Pak Ukraina. Fabryka puszek aluminiowych. Inwestycja kosztowała $35 \mathrm{mln}$ USD.

Również w 2003 roku z wielką inwestycją na rynek ukraiński wkroczyły Toruńskie Zakłady Materiałów Opatrunkowych. Wówczas rozpoczęto budowę fabryki „Bella-Trade”, a na początku następnego roku ruszyła produkcja materiałów opatrunkowych. Inwestycja kosztowała około $10 \mathrm{mln}$ USD. Tyleż samo w 2004 roku zainwestowała firma „Inter-Groclin” - producent pokryć do foteli samochodowych. Niższe o połowę koszty produkcji przekonały polskich przedsiębiorców do ulokowania kapitału w Użgorodzie, w obwodzie iwano-frankowskim. Także w tym roku polscy przedsiębiorcy zainwestowali ponad $2 \mathrm{mln}$ USD w produkcję wyrobów lateksowych, powołując spółkę „Perfekt”.

Zupełnie inaczej wyglądała sytuacja z lokowaniem środków przez ukraińskich przedsiębiorców w Polsce. Ich zaangażowanie na rynku polskim jest znikome. O niskiej aktywności inwestycyjnej świadczy chociażby brak danych statystycznych na ten temat na przestrzeni lat dziewięćdziesiątych. Do 2003 roku wartość ukraińskich inwestycji w Polsce nie osiągnęła nawet 400 tys. USD. Przełom nastąpił w 2004 roku, gdy suma ta przekroczyła 20 mln USD. Była to zapowiedź ekspansji inwestycyjnej, która nastąpiła w 2005 roku. Wówczas wartość ukraińskiego kapitału ulokowanego w Polsce przekroczyła $400 \mathrm{mln}$ USD. Stało się to dzięki dwóm wielkim inwestycjom Związku Przemysłowego Donbas i koncernu samochodowego „AutoZAZ”.

W czerwcu 2005 roku Związek Przemysłowy Donbas (ZPD)7 zainwestował w Hutę Częstochowa oraz 12 spółek zależnych. Łączna cena udziałów we wszystkich nabywanych spółkach przekroczyła $340 \mathrm{mln}$ USD. Inwestycja ta uratowała przed bankructwem zadłużoną firmę oraz utrzymała 5 tys. miejsc pracy. W następnym roku ukraiński inwestor ulokował w Polsce 34 mln USD, a na rok 2007 przewidywana wysokość inwestycji miała wynieść około $120 \mathrm{mln}$ USD. Związek Przemysłowy Donbas jest zainteresowany kupnem Walcowni Rur „Jedność” oraz Huty „Andrzej”. ZPD także zamierza zainwestować w polski

7 W przedsiębiorstwach ZPD jest zatrudnionych około 50 tys. osób. W 2004 roku przychody korporacji przekroczyły 2 mld USD. 
przemysł stoczniowy. Został już podpisany list intencyjny w sprawie zakupu 5\% akcji Stoczni Gdańskiej. Docelowo strona ukraińska jest zainteresowana kupnem większościowego pakietu akcji, których wartość przekracza $40 \mathrm{mln}$ USD.

Drugą wielką inwestycją ze strony Ukraińców było przejęcie warszawskiej Fabryki Samochodów Osobowych. Na przestrzeni ostatnich kilku lat Ukraina była największym importerem samochodów produkowanych przez to przedsiębiorstwo. Podczas gdy w roku 2000 na Ukrainę trafiło około 1300 aut, to już w 2004 wysłano ich ponad 39 tys. W 2005 roku FSO wysłała na Ukrainę stutysięczny samochód. Biorąc pod uwagę te okoliczności ukraiński koncern samochodowy „AwtoZAZ”, który był głównym odbiorcą polskich aut, zdecydował się w 2005 roku na zakup 19,9\% akcji FSO. Ukraiński inwestor wykupił długi przedsiębiorstwa, których wartość znacznie przekraczała 500 mln USD. $\mathrm{Na}$ bieżąco czyniono nowe inwestycje. Docelowo Ukraińcy ulokują w Polsce co najmniej $100 \mathrm{mln}$ USD. Jest to związane z modernizacją zakładu produkcyjnego i rozszerzeniem oferty. Od listopada 2007 roku ruszyła produkcja samochodów Chevrolet Aveo, które będą kierowane na rynki Europy Zachodniej.

\section{Sektor finansowy}

W latach dziewięćdziesiątych wiodącym obszarem inwestowania na Ukrainie był przemysł. Od 1997 roku drugim kierunkiem inwestowania pod względem wielkości ulokowanego przez Polaków kapitału stał się sektor finansowo-bankowy. Zaangażowanie polskiego kapitału w kolejnych latach uczyniło z Polski strategicznego partnera dla ukraińskiego sektora finansowego. Polskie inwestycje w bankowość obecnie są największymi inwestycjami zagranicznymi na Ukrainie.

W 1997 roku Kredyt Bank podpisał umowę o partnerstwie i współpracy z Zachodnio-Ukraińskim Bankiem Komercyjnym. W kolejnych latach Kredyt Bank rozpoczął wykupywanie udziałów banku ukraińskiego i w 2002 roku był już w posiadaniu 66\% akcji. Wartość inwestycji przekroczyła $25 \mathrm{mln}$ USD. Wówczas została zmieniona nazwa ukraińskiego banku na Kredyt Bank Ukraina. Gdy w 2004 roku władze banku podjęły decyzję o wycofaniu się z ukraińskiego rynku, nowym inwestorem Kredyt Banku Ukraina został PKO Bank Polski, który obecnie działa na Ukrainie pod nazwą Kredobank. Nie jest to bank w stu procentach polski, gdyż udziałowcami Kredobanku oprócz PKO BP, który posiada 69,93\% udziałów, jest Europejski Bank Odbudowy i Rozwoju oraz ukraińscy akcjonariusze.

Również w 1997 roku, w celu obsługi projektów realizowanych w ramach współpracy polsko-ukraińskiej, na Ukrainie rozpoczął działalność Bank Pekao SA jako Bank Pekao Ukraina. Był to jeden z pierwszych banków na Ukrainie ze stuprocentowym kapitałem zagranicznym. Swoją działalność rozpoczął w Łucku na Ukrainie Zachodniej. W kolejnych latach otworzył swoje oddziały w największych miastach w całym kraju. Wskutek wykupienia przez UniCredit Bank części udziałów w polskim Banku Pekao do grupy włoskiego banku wszedł 
również Bank Pekao Ukraina. Od 2006 roku ukraiński bank zmienił nazwę na UniCredit Bank.

W 2002 roku na Ukrainie Polskie Towarzystwo Reasekuracji, przejęło 25\% akcji „Skide-West”. Trzy lata później spółkę przejął Polski Zakład Ubezpieczeń. Wartość inwestycji wyniosła 1 mln USD.

\section{Współpraca energetyczna}

Kwestią fundamentalną dla gospodarki narodowej jest zaopatrzenie w ropę i gaz. Na przestrzeni kilku ostatnich lat w sposób szczególny odczuła to Ukraina, uzależniona prawie w stu procentach od Rosji. Kolejne podwyżki, które były odpowiedzią Kremla na prozachodnią politykę Kijowa, zapoczątkowały nowy etap w polityce energetycznej Ukrainy. Chodziło o dywersyfikację zaopatrzenia w surowce energetyczne, aby w ten sposób zabezpieczyć się przed Moskwą, narzucającą swoją wizję dla Ukrainy. Podobne tendencje miały miejsce również $\mathrm{w}$ Polsce. Zmierzając $\mathrm{w}$ kierunku UE i NATO polscy politycy zdawali sobie sprawę z niezadowolenia Rosji, które mogło spowodować szantaż energetyczny. Stąd też, wraz z zacieśnieniem współpracy politycznej i gospodarczej, Warszawa i Kijów zaczęły zastanawiać się nad formowaniem wspólnej polityki energetycznej i poszukiwaniem alternatywnych źródeł zaopatrzenia8. W 1999 roku utworzono polsko-ukraińskie przedsiębiorstwo Dewon S.A. z udziałem Polskiego Górnictwa Naftowego i Gazownictwa S.A. oraz „Naftogazu Ukrainy”. Podstawowym celem i zadaniem tej spółki była realizacja usług związanych z wydobyciem ropy naftowej i gazu ziemnego na terenie Ukrainy, co też nastąpiło w 2003 roku.

Głównym projektem energetycznym miał być projekt „Odessa - Brody”. Zanim ruszyła jego budowa, nie podejmowano żadnych konsultacji ze stroną Polską, co było błędem. Ukraina rozpoczęła budowę rurociągu łączącego terminal „Piwdennyj” na południu z przepompownią w Brodach w 1996 roku, a pierwsze rozmowy na temat jego ewentualnego przedłużenia na terytorium Polski przeprowadzono dopiero w 1998 roku, gdy jego budowa była już w trakcie realizacji.

26 listopada 2003 roku w Brukseli została zawarta Umowa między Rzadem Rzeczypospolitej Polskiej a Gabinetem Ministrów Ukrainy w sprawie użytkowania urzadzeń systemu transportu węglowodorów Odessa-Brody i ich integracji z polskimi urzadzeniami. Dokument ten nie zawiera żadnych przepisów szczegółowych. Określa natomiast ogólne zasady współpracy w tym zakresie

8 Współpraca energetyczna stała się szczególnie ważna po wydarzeniach, które miały miejsce na przełomie 2005/2006 roku. Wówczas wskutek braku porozumienia w sprawie ceny gazu Rosja zablokowała jego dostawy dla Ukrainy. Przykręcenie kurka polegało na zmniejszeniu ciśnienia gazu kierowanego do państw Europy Zachodniej, skutki czego były natychmiast odczuwalne w tych krajach. Negatywne reakcje ze strony tych państw oraz obawa przed kompromitacją zmusiły Kreml do kompromisowego rozwiązania. Na Ukrainie uznano to za sukces polityczny. Rosja bowiem chciała przejąć ukraińską sieć gazociągów w zamian za korzystną cenę za gaz. 
w oparciu o normy prawa europejskiego oraz ustanawia bezpośrednich wykonawców projektu po stronie polskiej i ukraińskiej. Powołano wówczas Komitet Sterujący odpowiedzialny za realizację projektu energetycznego. Współpraca ta zatrzymała się jednak na poziomie deklaracji. Chociaż podczas spotkań na różnych szczeblach ciągle pojawiają się zapowiedzi, budowa nitki rurociągowej w kierunku Płocka wciąż pozostaje na poziomie „inwestycji przyszłości”, której realizacja wydaje się być coraz bardziej wątpliwa z uwagi na rosyjską politykę energetyczną. Kreml realizuje własne plany, które mają na celu utrzymanie silnej pozycji w Europie oraz uniemożliwienie powstania alternatywnych dróg zaopatrzenia. Rosja zawarła porozumienie z Niemcami w zakresie wybudowania rurociągu na dnie Bałtyku oraz pakiet umów energetycznych z Grecją i Bułgarią w zakresie budowy rurociągu na dnie Morza Czarnego.

\section{Wnioski}

Współpraca gospodarcza między Polską i Ukrainą na przestrzeni kilku ostatnich lat rozwijała się bardzo dynamicznie. Wypracowana na przestrzeni lat dziewięćdziesiątych baza prawna stwarzała dobre ku temu warunki. Stąd też z roku na rok wzrastały wskaźniki wymiany handlowej, zwiększało się zaangażowanie inwestycyjne polskich przedsiębiorców na Ukrainie i ukraińskich w Polsce. Potencjał gospodarczy obu krajów jest jednak znacznie większy. Istotną przeszkodą, która z roku na rok staje się coraz bardziej uciążliwa, pozostaje granica polsko-ukraińska, a od 2004 roku - wschodnia granica Unii Europejskiej. Nie znikają kolejki po obu stronach granicy, w których kierowcy spędzają po kilkanaście godzin, a niekiedy po kilka dni. Budowa nowych przejść granicznych niewiele wniesie do poprawy tej sytuacji. Dobrym rozwiązaniem w tym zakresie byłoby wprowadzenie wspólnych odpraw. Taką możliwość stwarza zawarta w 2001 roku Umowa między Rzqdem Rzeczypospolitej Polskiej a Gabinetem Ministrów Ukrainy o wspótpracy przy dokonywaniu kontroli osób, towarów i środków transportu przekraczajacych polsko-ukrainska granice państwowa w ruchu drogowym i kolejowym. Obecnie na sześć granicznych przejść drogowych tylko na dwóch funkcjonuje wspólna odprawa. Pomimo tych trudności możemy jednak przypuszczać, że wartość wymiany handlowej w kolejnych latach nadal będzie rosła. Polska gospodarka aktywnie rozwija się, nieco gorzej jest z ukraińską. Niemniej jednak zacieśnienie kontaktów polityczno-gospodarczych Ukrainy z UE oraz jej wstąpienie do WTO rokuje nadzieję na wprowadzenie niezbędnych reform i szybki rozwój.

\section{Bibliografia}

Bidenko M., [15.05.1999], Obrij - na konwejeri, „Den”.

Cieślik M., [1992], Stosunki polsko-ukraińskie, „Rocznik Polskiej Polityki Zagranicznej”.

Cieślik M., [1999], Stosunki z Ukraina, „Rocznik Polskiej Polityki Zagranicznej”.

Deklaracja o zasadach i podstawowych kierunkach rozwoju stosunków polsko-ukrainskich,

[13.10.1990], „Zbiór Dokumentów”, nr 4. 
Fedorowicz K., [2004], Ukraina w polskiej polityce wschodniej w latach 1989-1999, Poznań.

Frelak J., [2005], Praca Ukrainców w Polsce - rekomendacje dla polityki migracyjnej, Instytut Spraw Publicznych, Analizy i Opinie, nr 38.

Górka K., [2002], Powiazania gospodarcze Polski z Ukrainq, [w:] Stosunki polsko-ukraińskie w zmieniajacych się uwarunkowaniach europejskich, (red.) J. Posłuszny, P. Steciuk, Przemyśl.

Kowalski M., [1998], Wpływ handlu z Ukrainq na rozwój województw przygranicznych, „Gospodarka Narodowa", nr 2-3.

Olszański T.A., [1998], Stosunki z Ukraina, „Rocznik Polskiej Polityki Zagranicznej”.

Owdin W., [2001], Na bezrybji, „Dzerkało Tyżnia”, nr 3 (327).

Paraszczak O., [2004], Skide-West = PZU Ukraina, „Strachowa Sprawa”, nr 4(16).

Paszewski T., [2000], Wptyw wejścia Polski do Unii Europejskiej na stosunki handlowe z Rosja, Litwa, Białorusiq, Ukraina i Stowacja, [w:] Polska granica wschodnia granica Unii Europejskiej, (red.) T. Paszewski, Centrum Stosunków Międzynarodowych, „Raporty i Analizy”, nr 7.

Polska firma Can Pack na Ukrainie, [2004], „Rynek Wschodni - Partnerzy”, nr 2.

Polsko-ukraińska wspótpraca po 1 maja 2004 roku, [2004], „Rynek Wschodni - Partnerzy”, nr 4.

Polsko-ukraińskie rozmowy gospodarcze, [17.02.2006], Informacja Ministerstwa Gospodarki, http:// www.mgip.gov.pl/Wiadomosci/ARCHIWUM/ukraina_minister_170206.htm.

Polsko-ukrainskie stosunki gospodarcze w 2003 roku, [2004], „Rynek Wschodni - Partnerzy”, nr 6.

Porozumienie między Ministerstwem Gospodarki Przestrzennej i Budownictwa Rzeczypospolitej Polskiej a Państwowym Komitetem Ukrainy do Spraw Urbanistyki i Architektury o utworzeniu Polsko-Ukraińskiej Komisji Gospodarki Przestrzennej, [25.06.1996], Departament Prawny Ministerstwa Spraw Zagranicznych Rzeczypospolitej Polskiej, Warszawa.

Porozumienie o wspótpracy między Ministerstwem Gospodarki Przestrzennej i Budownictwa Rzeczypospolitej Polskiej a Ministerstwem Budownictwa i Architektury Ukrainy, [19.05.1994], Departament Prawny Ministerstwa Spraw Zagranicznych Rzeczypospolitej Polskiej, Kijów.

Postanowienie Gabinetu Ministrów Ukrainy o zasadach wydawania zezwolenia na pracę na Ukrainie dla obcokrajowców i osób bez obywatelstwa, Kijów, [1.11.1999], nr 2028, ze zmianami odpowiednio do postanowienia Gabinetu Ministrów Ukrainy nr 649 z dnia 12.05 .2002 oraz nr 892 z dnia 12.09.2005, Werchowna Rada Ukrajiny, Miżnarodni Dokumenty, Kabinet Ministriw Ukrajiny, nr 2028-99-r.

Priami inwestyciji z Ukrajiny w krajiny JS, 01.01.2004, Zownisznioekonomiczna dijalnist, Państwowy Komitet Statystyki Ukrainy, www.ukrastat.gov.ua.

Priami inwestyciji z Ukrajiny w krajiny JS, 01.01.2005, Zownisznioekonomiczna dijalnist, Państwowy Komitet Statystyki Ukrainy, www.ukrastat.gov.ua.

Rozporzadzenie Ministra Pracy i Polityki Społecznej w sprawie trybu i warunków wydawania zezwoleń na prace dla cudzoziemców, Warszawa, 21.07.2006, Dz.U. 2006, nr 141, poz. 1001 i 1002.

Traktat między Rzeczapospolitq Polska a Ukrainq o dobrym sqsiedztwie, przyjaznych stosunkach i wspótpracy, Warszawa, 18.05.1992, Dz.U. 1993, nr 125, poz. 573.

„Rocznik Statystyczny Handlu Zagranicznego”, GUS, Warszawa, Wydania z lat 1993-2006.

Rozporzqdzenie Ministra Pracy i Polityki Społecznej w sprawie wykonywania pracy przez cudzoziemców bez konieczności uzyskania zezwolenia na pracę, 30.08.2006, Dz.U. 2006, nr 156, poz. 1116.

Rozporzadzenie Ministra Pracy i Polityki Społecznej zmieniajace rozporzadzenie w sprawie wykonywania pracy przez cudzoziemców bez konieczności uzyskania zezwolenia na pracę, 27.06.2007, Dz.U. 2007, nr 120, poz. 824.

Rozporzadzenie Ministra Pracy i Polityki Społecznej zmieniajace rozporzadzenie w sprawie wykonywania pracy przez cudzoziemców bez konieczności uzyskania zezwolenia na prace, 29.01.2008, Dz.U. 2008, nr 17, poz. 106.

Stan torhowelno-ekonomicznych widnosyn ta inwestycijnoji dijalnosti miz Ukrajinoju ta Respublikoju Polszcza, [2006], Materiały Generalnego Konsulatu Ukrainy w Krakowie. 
Staniszewski R., [1997], Stan i tendencje polsko-ukraińskich stosunków gospodarczych, Centrum Badań Wschodnich Uniwersytetu Warszawskiego, Warszawa.

Ślusarczyk B., [2004], Wspótpraca gospodarcza Polski z Ukraina, [w:] Wspótpraca gospodarcza Polski z krajami sasiednimi w okresie transformacji, (red.) J. Misala, Radom.

Ukraiński rynek maszyn rolniczych, [2004], „Rynek - Wschodni Partnerzy”, nr 9.

Umowa między Ministerstwem Pracy i Polityki Społecznej a Ministrem Pracy Ukrainy o wspótpracy $w$ dziedzinie pracy i polityki społecznej, Warszawa, 16.02.1994, Werchowna Rada Ukrajiny, Miżnarodni Dokumenty, Polszcza, nr 616_040.

Umowa między Rządem Rzeczypospolitej Polskiej a Rządem Ukrainy o handlu i wspótpracy gospodarczej, Warszawa, 4.10.1991, Departament Prawny Ministerstwa Spraw Zagranicznych Rzeczypospolitej Polskiej.

Umowa między Rzadem Rzeczypospolitej Polskiej a Rzadem Ukrainy o komunikacji lotniczej, Warszawa, 20.01.1994, Departament Prawny Ministerstwa Spraw Zagranicznych Rzeczypospolitej Polskiej.

Umowa między Rządem Rzeczypospolitej Polskiej a Rzadem Ukrainy o międzynarodowych przewozach drogowych, Warszawa, 18.05.1992, M.P. 2002, nr 6, poz. 125.

Umowa między Rzqdem Rzeczypospolitej Polskiej a Rzqdem Ukrainy o ruchu bezwizowym, Warszawa, 25.06.1996, „Zbiór Dokumentów”, 1997, nr 3.

Umowa między Rzq̨dem Rzeczypospolitej Polskiej a Gabinetem Ministrów Ukrainy w sprawie użytkowania urzadzeń systemu transportu węglowodorów Odessa-Brody i ich integracji z polskimi urzadzeniami, Bruksela, 26.11.2003, Departament Prawny Ministerstwa Spraw Zagranicznych Rzeczypospolitej Polskiej.

Umowa między Rządem Rzeczypospolitej Polskiej a Rządem Ukrainy o wzajemnym zatrudnianiu pracowników, Warszawa, 16.02.1994, Departament Prawny Ministerstwa Spraw Zagranicznych Rzeczypospolitej Polskiej.

Umowa między Rządem Rzeczypospolitej Polskiej a Gabinetem Ministrów Ukrainy o zasadach ruchu osobowego, Kijów, 30.07.2003, M.P. 2003, nr 56, poz. 878.

Urbanowska J., Oniszczuk W., Borko H., [2005], Ukraina: przewodnik dla przedsiębiorców, Warszawa.

Wspótpraca polsko-ukraińska, [2004], Wydział Ekonomiczno-Handlowy Ambasady RP w Kijowie, http://www.wehukraina.org/pol/war_dost.html.

\section{ECONOMIC COOPERATION BETWEEN POLAND AND UKRAINE}

\section{Sum mary}

The article focuses on economic cooperation between Poland and Ukraine. The author analyzes documents and legal regulations governing this cooperation. The paper compares statistical data on trade between the two countries and bilateral investment in industry, financial services and the energy sector. The main purpose of the paper is to show that bilateral economic relations are stable and testify to the existence of a strategic partnership between Poland and Ukraine. The analysis of bilateral agreements reveals that the existing legal framework is sufficiently developed to encourage further investment and economic cooperation between Poland and Ukraine. Moreover, many Polish investment projects in Ukraine and Ukrainian projects in Poland confirm that there is a high level of mutual interest. Another conclusion is that the limited capacity of the Polish-Ukrainian border poses a major obstacle to the development of bilateral 
cooperation. To remedy this problem, it is necessary to make better use of all available legal instruments and introduce joint customs and border clearance at all border crossings between the two countries, Kuspys says.

Keywords: economic cooperation, Poland, Ukraine, bilateral trade 